\title{
Adherence to long-term therapies in cystic fibrosis: a French cross-sectional study linking prescribing, dispensing, and hospitalization data
}

This article was published in the following Dove Press journal: Patient Preference and Adherence

\author{
Héloïse Rouzél,2 \\ Marie Viprey ${ }^{1,2}$ \\ Samuel Allemann ${ }^{2}$ \\ Alexandra L Dima $\mathbb{D}^{2}$ \\ Pascal Caillet ${ }^{3}$ \\ Angélique Denis' \\ Stéphanie Poupon-Bourdy \\ Boubou Camara ${ }^{4}$ \\ Catherine Llerena ${ }^{5}$ \\ Philippe Reix ${ }^{6}$ \\ Isabelle Durieu ${ }^{2,7}$ \\ Quitterie Reynaud ${ }^{2,7}$ \\ Sandrine Touzet ${ }^{1,2}$ \\ 'Public Health Department, Hospices \\ Civils de Lyon, Lyon, France; ${ }^{2} \mathrm{HESPER}$ \\ Lab-EA 7425, Université de Lyon- \\ Université Claude Bernard Lyon I, Lyon, \\ France; ${ }^{3}$ Department of Clinical \\ Pharmacology, CHU de Nantes, Nantes, \\ France; ${ }^{4}$ Pulmonary Department, Adult \\ CF Center, CHU de Grenoble, Grenoble, \\ France; ${ }^{5}$ Pediatric Pulmonology \\ Department, Pediatric CF Center, CHU \\ de Grenoble, Grenoble, France; \\ ${ }^{6}$ Pediatric Pulmonology Department, \\ Pediatric CF Center, Hôpital Femme- \\ Mère-Enfant, Hospices Civils de Lyon, \\ Lyon, France; ${ }^{7}$ Department of Internal \\ Medicine, Adult Cystic Fibrosis Care \\ Center, Centre Hospitalier Lyon Sud, \\ Hospices Civils de Lyon, Lyon, France
}

Correspondence: Héloïse Rouzé Hospices Civils de Lyon, Pôle de Santé Publique, Bâtiment A, 6ème étage, 162 Avenue Lacassagne 69003 Lyon, France $\mathrm{Tel}+33472115132$

Email heloise.rouze@chu-lyon.fr
Background: Cystic fibrosis (CF) is a life-shortening genetic condition that usually affects several organs and involves significant treatment burden. Adherence to medication is important for successful CF management.

Objective: To describe medication adherence according to age, therapeutic class, and pharmaceutical form in adults and children followed in four regional CF centers in France.

Methods: We conducted a cross-sectional study with non-transplanted patients followed in two adult and two pediatric centers during 2015 who were covered by the French National Health Insurance (NHI). Sociodemographic, clinical, hospitalization, and prescription data were collected from patient medical records. Medication dispensations were extracted from the regional French NHI database. Adherence was calculated over 12 months using continuous medication availability (CMA) accounting for dose adjustments and hospitalizations. Drug-specific CMA was computed in $\mathrm{R}$ with the Adhere R package for each medication prescribed more than 3 months, which was averaged to obtain a composite CMA score (cCMA) for all treatments and per therapeutic class as well as pharmaceutical form for each patient.

Results: A total of 228 patients were included. The number of chronic medications increased with age $(r=0.50, p<0.001)$ : a median of 7 medications per patient were prescribed. The mean \pm SD cCMA was significantly different between age groups ( $p=0.0098)$ : it was 0.71 \pm 0.20 for the $0-5$ years age group, $0.73 \pm 0.16$ for $6-11$ years, $0.64 \pm 0.17$ for $12-17$ years, 0.57 \pm 0.23 for $18-25$ years, and $0.65 \pm 0.20$ for the over 25 years age group. cCMA varied significantly according to pharmaceutical forms: the mean \pm SD cCMA was $0.70 \pm 0.21$ for oral medications and $0.54 \pm 0.28$ for inhaled medications $(p<0.001)$.

Conclusion: This study suggests that adherence to medication regimens in CF patients remains suboptimal and varies substantially between age groups and pharmaceutical forms. These variations in adherence should be considered when developing effective strategies to improve adherence.

Keywords: cystic fibrosis, chronic treatment, medication adherence, administrative claims data, prescription data

\section{Background}

Cystic fibrosis (CF) is a life-shortening inherited disease that usually affects several organs, although pulmonary disease predominately contributes to morbidity and mortality. In France, the use of new treatment strategies and systematization of early diagnosis since 2002 have led to a significant improvement in survival, and today there are more adult patients than children. ${ }^{1,2}$ However, CF remains a chronic 
and progressive disease and requires multiple life-long therapies that require daily and time-consuming administration. $^{3}$ Treatment generally comprises of the daily intake of pancreatic enzymes, nutritional supplements, airway clearance, physiotherapy, inhaled or nebulized medications (mucolytics, antibiotics, and bronchodilators), and oral medications such as anti-inflammatories and antibiotics, not to mention the management of comorbidities such as CF-related diabetes. ${ }^{3-5}$

The treatment burden of CF raises the question of medication adherence. Published studies have reported adherence that ranges from $35 \%$ to $75 \%$ according to the age of the population, therapeutic class, and regimen complexity studied, but also the method used to estimate this. ${ }^{6,7}$ Furthermore, low adherence is reported to negatively influence health outcomes, such as pulmonary exacerbations, ${ }^{8-10}$ health care costs (primarily owing to an increase in hospitalizations), ${ }^{11,12}$ and quality of life. ${ }^{13,14}$ Published studies used different methods of measurement, such as selfreport (a subjective method), electronic measurement or administrative claims data (objective method), and considered different time periods (a few weeks to several months) and populations (children, adults), making comparisons difficult. $^{6,7}$ Furthermore, the majority of studies evaluated one or two drugs or therapeutic classes, the most studied class being the drugs of respiratory system, ${ }^{7}$ which is only part of the treatment regimen. It therefore seems interesting to investigate the whole $\mathrm{CF}$ medication regimen for all ages. The aim of the present study was to describe medication adherence in adults and children followed in four regional $\mathrm{CF}$ centers in France, combining prescription data and administrative claims data, and to investigate this according to age, therapeutic class, and pharmaceutical form.

\section{Methods}

\section{Design, setting, and sample selection}

A multicentre cross-sectional study was conducted among CF patients receiving care in four (two pediatric and two adult) regional CF centers in the RhôneAlpes region of France during 2015. Inclusion criteria were: documented $\mathrm{CF}$ diagnosis by a $\mathrm{CF}$ specialist physician, at least one chronic CF treatment prescribed more than 3 months during the follow-up period, covered by the French National Health Insurance (NHI), and living in the Rhône-Alpes region in 2015. Transplanted patients were excluded. All patients registered in the four regional $\mathrm{CF}$ centers received an invitation by post to participate in the study. Written informed consent was obtained from adult CF patients and from the parents of children with CF. The study was approved by the ethics committee of the university hospital of Lyon and the French national data protection authority (reference DR 2015 391).

\section{Demographic and clinical data}

We extracted the following demographic and clinical data from medical records: gender, age, age at CF diagnosis, context of diagnosis, cystic fibrosis transmembrane conductance regulator (CFTR) genotype, Pseudomonas aeruginosa colonization status, presence of CF-related diabetes, body mass index at the last visit to the CF center before 1 January 2015. The FEV 1 collected was the best value during 2014, and was expressed as percentage of the predicted value according to Knudson's reference. Occurrence and total duration of course of intravenous (IV) antibiotic courses, number of outpatient visits in $\mathrm{CF}$ centers, and occurrence and total duration of hospitalizations were collected for 2014. Prescription data for medications prescribed more than 3 months (name of drugs, pharmaceutical forms, dosage, and durations of prescription) were collected from the prescription made on the last visit prior to 1 January 2015 and throughout 2015. Parenthood, marital status, and professional situation data were also collected for adult patients. These data were collected in all four CF centers and anonymized before analysis.

\section{Administrative claims data}

Administrative claims data were provided by the regional reimbursement database (Extraction, Recherches, Analyses pour un Suivi Medico-Economique, ERASME). This database contains information on all reimbursement data for patients affiliated to the main French NHI living in the Rhône-Alpes area, including drugs and hospitalizations ordered by physicians, for the previous 24-month period. ${ }^{15}$ We focused on ten therapeutic classes as follows (drug names are presented in Table S1): drugs for obstructive airways disease (ie, beta-2-adrenoreceptor agonist or glucocorticoid aerosol), mucolytics (dornase alfa), inhaled anti-infectives (ie, colistin or tobramycin), oral anti-infectives (ie, azithromycin or itraconazole), CFTR potentiator (ivafactor), drugs for acid-related disorders, digestive enzymes (lipase and protease), bile acids, vitamins and mineral supplements (ie, calcium or tocopherol), and antidiabetics (insulin and oral hypoglycaemic drugs such as 
repaglinide). There is no consensus on the medication threshold defining polypharmacy; thresholds used range from 5 to 10 drugs. ${ }^{16,17}$ Herein, a threshold of $>7$ drugs was used as this is reported elsewhere to be the median number of daily drugs prescribed to $\mathrm{CF}$ patients. ${ }^{3}$

\section{Adherence measurement}

We derived a measure for adherence combining prescription data and administrative claims data. Administrative claims data provide an objective estimate of adherence for multiple medications, large samples, long follow-up periods, at low cost, and without intrusion. ${ }^{18,19}$ We calculated adherence using continuous medication availability (CMA) which evaluates both implementation (to take medication in accordance with the recommended dosing regimen) and persistence (to continue taking it for the recommended duration). ${ }^{20}$ We used CMA version 7 to calculate adherence during the prescription period; this is defined as the proportion of days covered by a medication during the observation window (OW; ie, the period for which adherence is calculated), for each individual medication. ${ }^{21}$ Briefly, CMA version 7 assumes that dispensed medications are used as prescribed and oversupply from previous dispensing events is finished before a new supply is used. ${ }^{18}$ It accounts for dispensing events within the whole follow-up window (FUW; ie, the total period for which relevant medication events are recorded), meaning that oversupply can be carried into the OW. Remaining supply at the end of the OW is excluded. If the first dispensing event during the FUW preceded the first recorded prescription event, we calculated the duration of the supply with the dosage of the first recorded prescription. When patients were hospitalized, we assumed that treatments were supplied by the hospital during the entire hospitalization period, excluding the day of admission, and remaining supplies were extended accordingly. After each prescription change (for example, dosage modification), we recalculated the duration of the remaining supply.

In the present study, the FUW contained all medication events between July 2014 and June 2016, and the OW covered the year 2015 (from 01/01/2015 to 31/12/2015). To adequately estimate adherence for chronic treatments, calculations included only medications prescribed for more than 3 months, with at least one dispensing event during the FUW.

The CMAs of each individual medication could be averaged to obtain a composite CMA (cCMA). ${ }^{22}$ In case of one-drug regimen, the cCMA would be equal to the
CMA of that individual drug. For each patient, cCMA was obtained for each therapeutic class, for oral and inhaled pharmaceutical form (PO_cCMA and Inhal_cCMA, respectively) and for the entire treatment regimen (overall cCMA). Patients were considered "adherent" if cCMA was 0.80 or above. We used AdhereR, an open-source package for the widely used open-source environment $\mathrm{R}$, to calculate CMA and cCMA. ${ }^{21,23}$

\section{Statistical analyses}

Mean and SD or median and (range) for continuous variables and frequency and percentage for categorical variables were used to summarize demographic and clinical characteristics as well as the adherence rate. Chi-square tests were used to compare age and gender between patients included and those who were not included. We analyzed the data according to five age groups consistent with stages of illness and treatment of CF patients: $0-5$ years, 6-11 years, 12-17 years, 18-25 years, and 26 or older. Correlations between age and number of medications were assessed by the Spearman's test. We compared cCMA for each therapeutic classes, PO_cCMA, Inhal_cCMA and overall cCMA by age group and pharmaceutical forms using the Kruskal-Wallis test. The significance level was set at 0.05 throughout. Statistical analyses were performed using SAS version 9.2 (SAS Institute, Inc., Cary, NC, US).

\section{Results}

\section{Patient characteristics}

Of the $613 \mathrm{CF}$ patients invited to participate among the 801 followed in the four regional CF centers in 2015, a total of 287 patients consented. Complete refill and medical records could be extracted for 231 patients. Three participants did not have any treatment prescribed for more than 3 months, resulting in a sample of 228 patients composed of 135 children and 93 adults (Figure 1).

There was no significant difference in terms of age between the 228 patients included and the 385 patients who were not included $(21.1 \%$ versus $14.0 \%$ for patients aged $0-5$ years; $21.1 \%$ versus $23.1 \%$ for those aged $6-11$ years; $17.1 \%$ versus $17.7 \%$ for those aged $12-17$ years; $14.9 \%$ versus $17.9 \%$ for those aged $18-25$ years, and $25.9 \%$ versus $27.3 \%$ for those aged 26 years or older; $p=0.247)$ and no significant difference in terms of gender (45.2\% versus $47.5 \% ; p=0.571)$. 


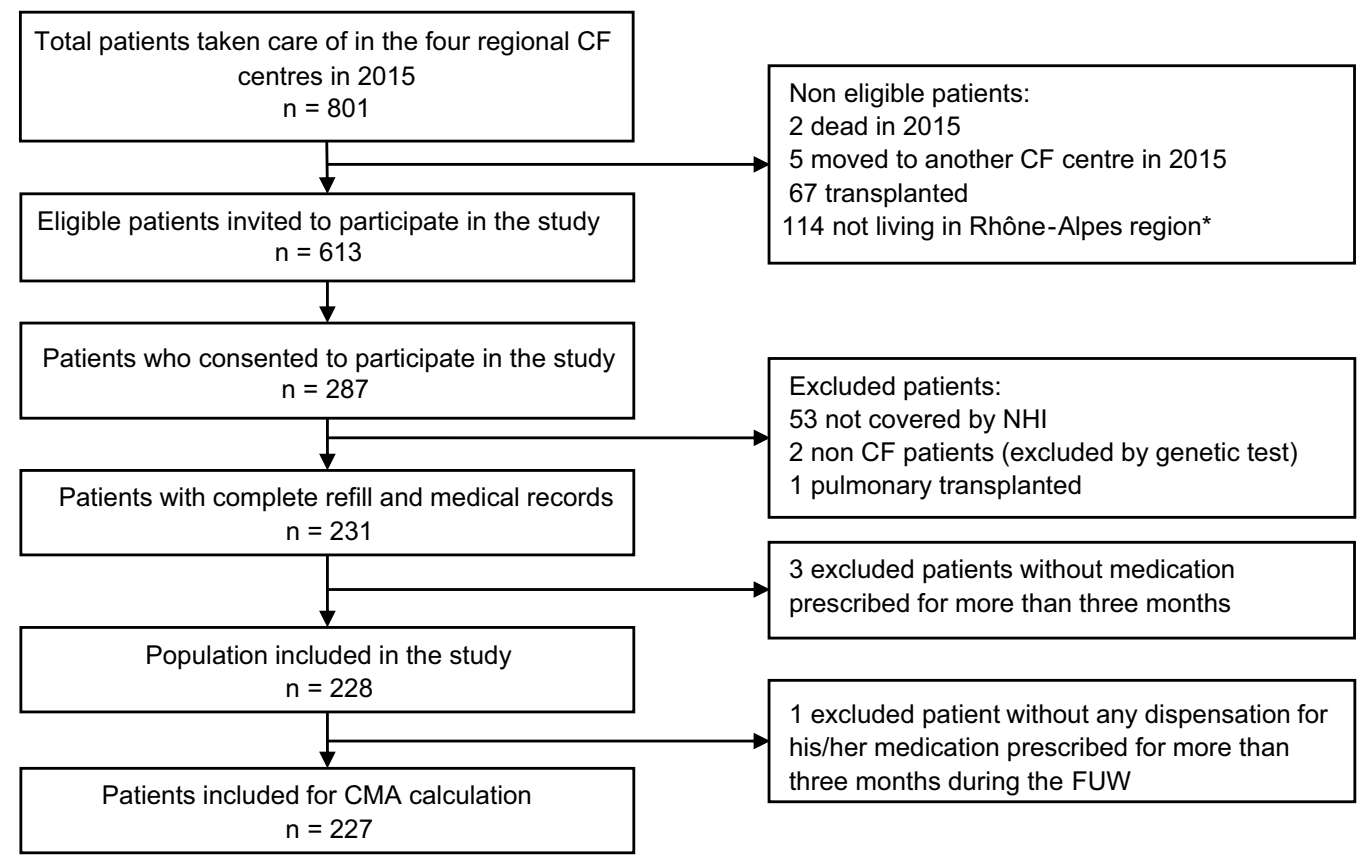

Figure I Flow chart for the study.

Note: *No administrative claims data in "ERASME" database.

Abbreviations: CF, cystic fibrosis; NHI, National Health Insurance; FUW, follow-up window (total period for which relevant medication events were recorded); CMA, continuous medication availability (adherence estimation).

Almost all patients of the $0-5$ and 6-11 years groups (94/96) were diagnosed before the first year of life versus less than two-thirds of other age groups (81/132). While $12.5 \%(6 / 48)$ of the 6-11 group had one or more IV antibiotic courses in 2014 , this rate rose to $43.8 \%$ (32/ 73 ) of the 12-25 years old and 57.6\% (34/59) of the 26 and older group. In parallel, 91.7\% (44/48) of the patients aged 6-11 years and 33.9\% (20/59) of those aged 26 years or older had mild disease (FEV1\% $\geq 70 \%$ ). For all groups of patients, mean outpatient visits in CF-center was 4.8 \pm 2.4 by year. The adult patients aged $18-25$ years were mostly students $(55.9 \%)$, single $(72.7 \%)$, and without children $(94.1 \%)$, and those aged 26 years or more were mostly working $(83.0 \%)$, in a relationship (67.2\%) and $30 \%$ of them had at least one child (Table 1 ).

\section{Treatment regimen}

The number of chronic medications increased significantly with age from 4 for young children to 9 for adults $(\mathrm{r}=0.50$; $p<0.001$ ), with a median number of 8 (range 1-15) chronic medications among patients aged 6 and more. Eight or more chronic medications (polypharmacy) were prescribed to $39.6 \%$ of patients aged $6-11$ years, $53.9 \%$ of those aged $12-17$ years, $61.8 \%$ of those aged $18-25$ years, and $66.1 \%$ of those aged 26 years or older patients. Digestive enzymes and vitamins were prescribed in $79-100 \%$ of patients. Among inhaled medication prescriptions, 18.8\% of patients aged $0-5$ years had mucolytics (such as dornase alfa) whereas these drugs were prescribed to $63.9 \%$ (115/ 180) of older patients. For inhaled anti-infectives, the prescription rates were $14.6 \%$ in patients aged $0-5$ years, $35.4 \%$ in those aged 5-11 years, and 68.2\% (90/132) in those aged over 11 years; for oral anti-infectives $32.3 \%$ (31/96) of those aged $0-11$ years and 69.7\% (92/132) of older patients had at least one prescription for oral antiinfectives for more than 3 months (Table 2).

\section{Medication adherence}

One patient had no dispensation from the beginning of FUW until the end of the OW for any of his medications prescribed for more than 3 months, and therefore CMA was calculated for 227 patients. Sixty-seven patients had at least one prescribed medication that was not dispensed from the beginning of the FUW until the end of the OW. For these medications, no CMA was calculated.

The mean $\pm \mathrm{SD}$ cCMA for all medications (overall cCMA) ranged from $0.57 \pm 0.23$ to $0.73 \pm 0.16$, and there was a significant difference between age groups (Table 3 and Figure 2). The proportion of patients classified as adherent (cCMA of 0.80 or above) was $39.6 \%$ (19/48) in patients aged 
Table I Baseline characteristics of the patients according to age $(N=228)$

\begin{tabular}{|c|c|c|c|c|c|}
\hline & $\begin{array}{l}0-5 \text { years } \\
\text { old }\end{array}$ & $\begin{array}{l}6-11 \text { years } \\
\text { old }\end{array}$ & $\begin{array}{l}\text { I2-17 years } \\
\text { old }\end{array}$ & $\begin{array}{l}\text { I8-25 years } \\
\text { old }\end{array}$ & 26 and over \\
\hline & $n=48$ & $n=48$ & $n=39$ & $n=34$ & $n=59$ \\
\hline Mean age, years $\pm S D$ & $2.5 \pm 1.8$ & $8.5 \pm 1.6$ & $15.1 \pm 1.67$ & $21.1 \pm 2.4$ & $34.5 \pm 8.8$ \\
\hline Gender, (male/female) & $31 / 17$ & $27 / 21$ & $20 / 19$ & $20 / 14$ & $27 / 32$ \\
\hline $\begin{array}{l}\text { Diagnostic pattern, } \mathrm{n}(\%) \\
\text { Screening } \\
\text { Symptoms } \\
\text { Family history } \\
\text { Missing data }\end{array}$ & $\begin{array}{l}46(95.8) \\
2(4.2) \\
0 \\
0\end{array}$ & $\begin{array}{l}45(93.8) \\
3(6.3) \\
0 \\
0\end{array}$ & $\begin{array}{l}4(10.3) \\
32(82.0) \\
3(7.7) \\
0\end{array}$ & $\begin{array}{l}7(22.6) \\
24(77.4) \\
0 \\
3\end{array}$ & $\begin{array}{l}6(12.4) \\
40(81.6) \\
3(6.1) \\
10\end{array}$ \\
\hline $\begin{array}{l}\text { Age in years at CF diagnosis, } n(\%) \\
\quad \leq 1 \\
>1\end{array}$ & $\begin{array}{l}48(100) \\
0\end{array}$ & $\begin{array}{l}46(95.8) \\
2(4.2)\end{array}$ & $\begin{array}{l}27(69.2) \\
12(30.8)\end{array}$ & $\begin{array}{l}21(61.8) \\
13(38.2)\end{array}$ & $\begin{array}{l}33(55.9) \\
26(44.1)\end{array}$ \\
\hline $\begin{array}{l}\text { Mutation n (\%) } \\
\text { Homozygous DeltaF508 } \\
\text { Heterozygous DeltaF508 } \\
\text { Other }\end{array}$ & $\begin{array}{l}20(41.7) \\
19(39.6) \\
9(27.3)\end{array}$ & $\begin{array}{l}15(31.3) \\
23(47.9) \\
10(20.8)\end{array}$ & $\begin{array}{l}23(59.0) \\
14(35.9) \\
2(5.1)\end{array}$ & $\begin{array}{l}15(44.1) \\
15(44.1) \\
4(11.8)\end{array}$ & $\begin{array}{l}19(32.2) \\
32(54.2) \\
8(24.2)\end{array}$ \\
\hline Pseudomonas aeruginosa colonization status, $\mathrm{n}(\%)$ & $\mathrm{I}(2.1)$ & $6(12.5)$ & $14(35.9)$ & $15(44.1)$ & $38(64.4)$ \\
\hline $\begin{array}{l}\text { Best forced expiratory volume percent predicted (FEVI\%), } \\
\text { mean } \pm \text { SD }\end{array}$ & & $99 \pm 17$ & $95 \pm 20$ & $76 \pm 21$ & $64 \pm 19$ \\
\hline $\begin{array}{l}\text { Severity of disease (patients }>6 \text { years), } \mathrm{n}(\%) \\
\text { Mild: } \mathrm{FEVI} \% \geq 70 \% \\
\text { Moderate: } 40 \% \leq \mathrm{FEVI} \%<70 \% \\
\text { Severe: } 40 \%<\mathrm{FEVI} \%\end{array}$ & & $\begin{array}{l}44(91.7) \\
4(8.3) \\
0\end{array}$ & $\begin{array}{l}35(89.7) \\
4(10.3) \\
0\end{array}$ & $\begin{array}{l}23(67.7) \\
10(29.4) \\
1(2.9)\end{array}$ & $\begin{array}{l}20(33.9) \\
31(52.5) \\
8(13.6)\end{array}$ \\
\hline $\begin{array}{l}\text { Body mass index }{ }^{a}, \mathrm{n}(\%) \\
\text { Normal }^{\mathrm{b}} \\
\text { Subnormal }^{\mathrm{c}}\end{array}$ & $\begin{array}{l}10(20.8) \\
20(4 I .7)\end{array}$ & $\begin{array}{l}15(31.3) \\
33(68.7)\end{array}$ & $\begin{array}{l}7(17.9) \\
32(82.1)\end{array}$ & $\begin{array}{l}26(76.5) \\
8(23.5)\end{array}$ & $\begin{array}{l}50(84.7) \\
9(15.3)\end{array}$ \\
\hline $\begin{array}{l}\text { CF-related diabetes, } \mathrm{n}(\%) \\
\text { Insulin-dependent diabetes } \\
\text { Non insulin-dependent diabetes } \\
\text { Glucose intolerance }\end{array}$ & $\begin{array}{l}0 \\
0 \\
0\end{array}$ & $\begin{array}{l}0 \\
0 \\
I(2 . I)\end{array}$ & $\begin{array}{l}1(2.6) \\
2(5.1) \\
12(30.8)\end{array}$ & $\begin{array}{l}5(14.7) \\
0 \\
2(5.9)\end{array}$ & $\begin{array}{l}10(16.9) \\
4(6.8) \\
5(8.5)\end{array}$ \\
\hline $\begin{array}{l}\text { IV antibiotics courses in } 2014, \mathrm{n}(\%) \\
0 \\
\mathrm{I}-2 \\
3+\end{array}$ & $\begin{array}{l}48(100) \\
0 \\
0\end{array}$ & $\begin{array}{l}42(87.5) \\
6(12.5) \\
0\end{array}$ & $\begin{array}{l}21(53.9) \\
15(38.5) \\
3(7.7)\end{array}$ & $\begin{array}{l}20(58.8) \\
12(35.3) \\
2(5.9)\end{array}$ & $\begin{array}{l}25(42.4) \\
25(42.4) \\
9(15.3)\end{array}$ \\
\hline $\begin{array}{l}\text { Days with IV antibiotics courses, } \\
\text { Median (range) }\end{array}$ & $\mathrm{n}=0$ & $\begin{array}{l}n=6 \\
14(14-50)\end{array}$ & $\begin{array}{l}n=18 \\
15(5-114)\end{array}$ & $\begin{array}{l}n=14 \\
22(14-59)\end{array}$ & $\begin{array}{l}n=34 \\
29.5(11-119)\end{array}$ \\
\hline Outpatient visits in CF-centers in 2014 , mean \pm SD & $4.1 \pm 1.7$ & $4.1 \pm 1.3$ & $5.7 \pm 2.9$ & $5.0 \pm 2.3$ & $5.0 \pm 3.0$ \\
\hline $\begin{array}{l}\text { Hospitalizations in 2014, n (\%) } \\
0 \\
\mathrm{I}+\end{array}$ & $\begin{array}{l}38(79.2) \\
10(20.8)\end{array}$ & $\begin{array}{l}42(87.5) \\
6(12.5)\end{array}$ & $\begin{array}{l}28(71.8) \\
I I(28.2)\end{array}$ & $\begin{array}{l}25(73.5) \\
9(26.5)\end{array}$ & $\begin{array}{l}42(71.2) \\
17(28.8)\end{array}$ \\
\hline $\begin{array}{l}\text { Days in hospital in 2014, } \\
\text { Median (range) }\end{array}$ & $\begin{array}{l}n=10 \\
3(2-55)\end{array}$ & $\begin{array}{l}n=6 \\
8(3-15)\end{array}$ & $\begin{array}{l}n=11 \\
7(2-43)\end{array}$ & $\begin{array}{l}n=9 \\
5(4-16)\end{array}$ & $\begin{array}{l}n=17 \\
I I(3-40)\end{array}$ \\
\hline
\end{tabular}

(Continued) 
Table I (Continued).

\begin{tabular}{|c|c|c|c|c|c|}
\hline & $\begin{array}{l}\text { 0-5 years } \\
\text { old }\end{array}$ & $\begin{array}{l}\text { 6-I I years } \\
\text { old }\end{array}$ & $\begin{array}{l}\text { I2-I7 years } \\
\text { old }\end{array}$ & $\begin{array}{l}\text { I 8-25 years } \\
\text { old }\end{array}$ & 26 and over \\
\hline & $n=48$ & $n=48$ & $n=39$ & $n=34$ & $n=59$ \\
\hline Parent with one child or more, $\mathrm{n}$ (\%) & & & & $2(5.9)$ & $18(30.5)$ \\
\hline $\begin{array}{l}\text { Marital status (adults), } \mathrm{n}(\%) \\
\text { In a relationship } \\
\text { Single } \\
\text { Missing data }\end{array}$ & & & & $\begin{array}{l}9(7.8) \\
24(72.7) \\
\text { I }\end{array}$ & $\begin{array}{l}39(67.2) \\
19(32.8) \\
1\end{array}$ \\
\hline $\begin{array}{l}\text { Professionnal situation (adults), n (\%) } \\
\text { Higher professional occupations } \\
\text { Intermediate professional occupations } \\
\text { Employees and technical occupations } \\
\text { Students or Unemployed }\end{array}$ & & & & $\begin{array}{l}2(5.9) \\
3(8.8) \\
10(29.4) \\
19(55.9)\end{array}$ & $\begin{array}{l}10(17.0) \\
16(27.1) \\
23(39.0) \\
10(17.0)\end{array}$ \\
\hline
\end{tabular}

Notes: ${ }^{\mathrm{B}}$ Body mass index (BMI) for patients over 18 years old or z-score BMI for patient between 2 and 18 years old; no data available for patients under 2 years old. ${ }^{\mathrm{b}} \mathrm{BMI}$ $\geq 18.5$ or $z$-score $B M I \geq 0$. ${ }^{\mathrm{C} B M I}<18.5$ or $\mathrm{z}$-score $\mathrm{BMI}<0$.

Abbreviations: $\mathrm{CF}$, cystic fibrosis; IV, intravenous.

Table 2 Description of CF-related treatments for all patients and according to age groups ( $N=228)$

\begin{tabular}{|c|c|c|c|c|c|c|}
\hline CF long-term Regimen & $\begin{array}{l}\text { All } \\
\text { patients } \\
\mathbf{n = 2 2 8}\end{array}$ & $\begin{array}{l}0-5 \text { years } \\
\text { old } \\
n=48\end{array}$ & $\begin{array}{l}6-11 \text { years } \\
\text { old } \\
n=48\end{array}$ & $\begin{array}{l}\text { I2-17 years } \\
\text { old } \\
n=39\end{array}$ & $\begin{array}{l}\text { I8-25 years } \\
\text { old } \\
n=34\end{array}$ & $\begin{array}{l}26 \text { and } \\
\text { over } \\
n=59\end{array}$ \\
\hline Number of drugs prescribed, mean $\pm S D$ & $7.1 \pm 3.1$ & $4.2 \pm 1.9$ & $6.4 \pm 2.4$ & $8.1 \pm 2.9$ & $8.7 \pm 2.8$ & $8.5 \pm 3.1$ \\
\hline \multicolumn{7}{|l|}{$\begin{array}{l}\text { Number of drugs prescribed median } \\
\text { (range) }\end{array}$} \\
\hline All drugs & $7(1-15)$ & $4(I-8)$ & $7(I-I I)$ & $8(1-15)$ & $9(3-14)$ & $9(1-15)$ \\
\hline Oral medications & $5(0-11)$ & $3(0-7)$ & $5(\mathrm{I}-8)$ & $6(1-9)$ & $6(I-9)$ & $6(0-11)$ \\
\hline Inhaled medications & $2(0-6)$ & I $(0-3)$ & $2(0-5)$ & $2(0-6)$ & $2(I-6)$ & $3(0-4)$ \\
\hline \multicolumn{7}{|l|}{ Number of drugs prescribed, $\mathrm{n}(\%)$} \\
\hline 0-7 medications & $126(55.3)$ & $46(95.8)$ & $29(60.4)$ & $18(46.1)$ & $13(38.2)$ & $20(33.9)$ \\
\hline$\geq 8$ & $102(44.7)$ & $2(4.2)$ & $19(39.6)$ & $21(53.9)$ & $21(61.8)$ & $39(66.1)$ \\
\hline \multicolumn{7}{|l|}{ Prescribed therapeutic class, $\mathrm{n}(\%)$} \\
\hline Oral medication & $225(98.7)$ & $47(97.9)$ & $48(100)$ & $39(100)$ & $34(100)$ & $58(98.3)$ \\
\hline CFTR potentiator & $4(1.8)$ & I (2.I) & I (2.I) & $2(5.1)$ & 0 & 0 \\
\hline Antidiabetics & $23(10.1)$ & 0 & 0 & I (2.6) & $6(17.6)$ & $16(27.1)$ \\
\hline Oral anti-infectives $^{\mathrm{a}}$ & $122(53.5)$ & $13(27.1)$ & $18(37.5)$ & $25(64.1)$ & $23(67.6)$ & $44(74.6)$ \\
\hline Digestive enzymes & $199(87.3)$ & $38(79.2)$ & $42(87.5)$ & $37(94.9)$ & $32(94.1)$ & $5 \mathrm{I}(86.4)$ \\
\hline Vitamins and mineral supplements & $216(94.7)$ & $44(91.7)$ & 47 (97.9) & $39(100)$ & $32(94.1)$ & $55(93.2)$ \\
\hline Bile acids & $59(25.9)$ & $2(4.2)$ & $9(18.8)$ & $19(48.7)$ & $14(4 \mid .2)$ & $16(27.1)$ \\
\hline Drugs for acid related disorders & $89(39.0)$ & $20(41.7)$ & $20(4 \mid .7)$ & $19(48.7)$ & $12(35.3)$ & $19(32.2)$ \\
\hline Inhaled medication & $187(82.0)$ & $24(50.0)$ & $42(87.5)$ & $36(92.3)$ & $34(100)$ & $56(94.9)$ \\
\hline Inhaled anti-infectives ${ }^{\mathrm{a}}$ & $113(49.6)$ & $7(14.6)$ & $17(35.4)$ & $28(71.8)$ & $24(70.6)$ & $38(64.4)$ \\
\hline Mucolytics & $123(53.9)$ & $9(18.8)$ & $29(60.4)$ & $25(64.1)$ & $27(79.4)$ & $34(57.6)$ \\
\hline Drugs for obstructive airways disease & $130(57.3)$ & $15(31.3)$ & $28(58.3)$ & $20(5 \mid .3)$ & $21(61.8)$ & $49(83.1)$ \\
\hline
\end{tabular}

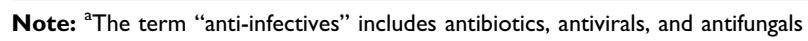

Abbreviations: CF, cystic fibrosis; CFTR, cystic fibrosis transmembrane conductance regulator. 


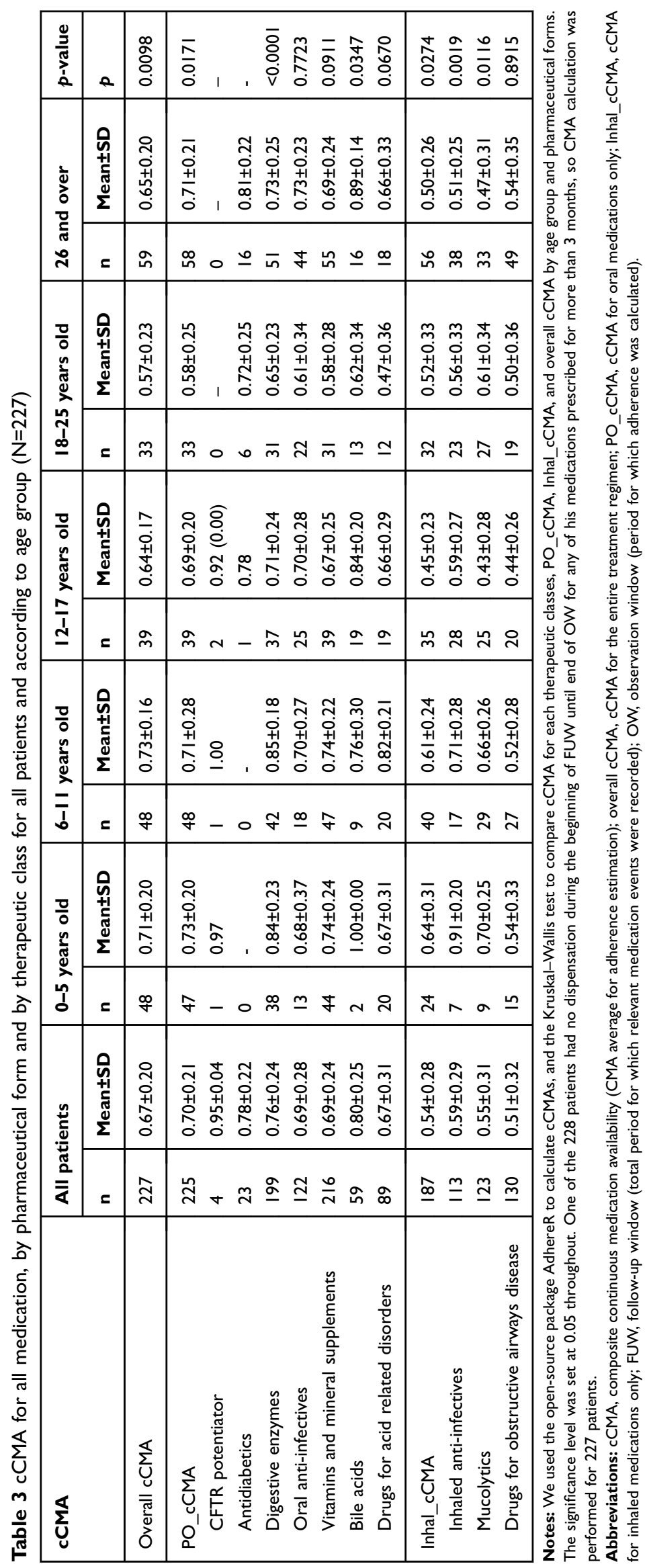




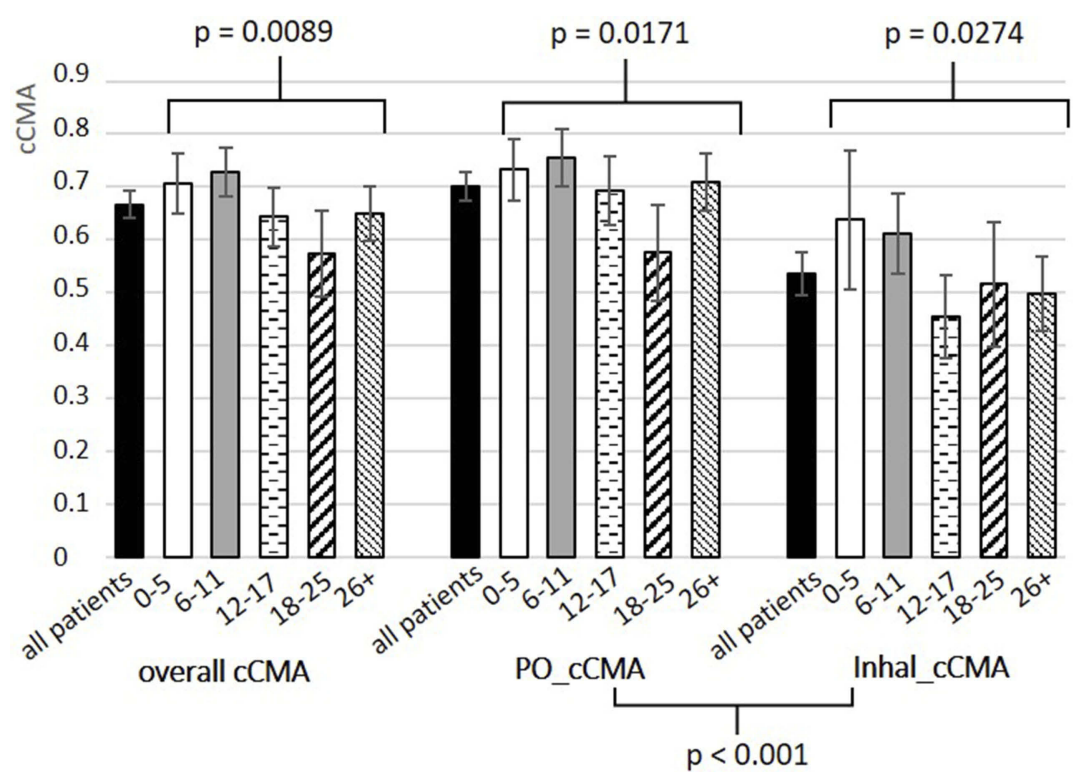

Figure 2 Mean cCMA and 95\% confidence interval for all medication (overall cCMA), oral medication (PO_cCMA) and inhaled medication (Inhal_cCMA) according to age. Notes: We used the open-source package AdhereR to calculate cCMAs, and the Kruskal-Wallis test to compare PO_cCMA, Inhal_cCMA, and overall cCMA by age group and pharmaceutical forms. The significance level was set at 0.05 throughout. One of the 228 patients had no dispensation during the beginning of FUW until end of OW for any of his medications prescribed for more than 3 months, so CMA calculation was performed for 227 patients.

Abbreviations: cCMA, composite continuous medication availability (CMA average for adherence estimation); overall cCMA, cCMA for the entire treatment regimen; PO_cCMA, cCMA for oral medications only; Inhal_cCMA, cCMA for inhaled medications only; FUW, follow-up window (total period for which relevant medication events were recorded); OW, observation window (period for which adherence was calculated).

0-5 years, 37.5\% (18/48) in those aged 6-11 years, $20.5 \%$ $(8 / 39)$ in those aged $12-17$ years, $21.2 \%(7 / 33)$ in those aged $18-25$ years, and $25.4 \%(15 / 59)$ in those aged 26 years or older patients.

There was a significant difference between age groups in mean cCMA for oral medications (PO_cCMA, $p=0.0171$; Table 3 and Figure 2), particularly for digestive enzymes $(p<0.0001)$, for which $71.1 \%$ (27/38) of patients aged $0-5$ years, $73.8 \%$ (31/42) of those aged 6-11 years, $43.2 \%(16 / 37)$ of those aged $12-17$ years, $25.8 \%(8 / 31)$ of those aged $18-25$ years, and $47.1 \%(24 / 51)$ of those aged 26 years or older patients had a CMA of 0.80 or above. There was no significant difference in adherence to multivitamins between age groups ( $p=0.0911$; Table 3$)$; the mean \pm SD cCMA was $0.66 \pm 0.26$.

Mean cCMAs were significantly different between age groups for inhaled drugs (Inhal_cCMA: $p=0.0274$; Table 3 and Figure 2); there was a significant difference for mucolytics $(p=0.0116)$ and inhaled anti-infectives $(p=0.0019)$, but not for bronchodilators $(p=0.8915)$. Adherence was significantly lower for inhaled drugs $(0.54 \pm 0.28)$ than for oral medication $(0.70 \pm 0.21, p<0.001$; Figure 2$)$.

Regarding inhaled forms of anti-infectives, mean cCMA decreased with age for inhaled forms: in this therapeutic class, mean \pm SD cCMA was $0.91 \pm 0.20$ in patients aged $0-5$ years, $0.71 \pm 0.28$ in those aged $5-11$ years, 0.59 \pm 0.27 in those aged $12-17$ years, $0.56 \pm 0.33$ in those aged $18-25$ years, and $0.51 \pm 0.25$ in those aged 26 years or older patients $(p<0.0001$; Table 3$)$, as did the proportion of adherent patients $(85.7 \%(6 / 7)$ of patients aged $0-5$ years; $47.1 \%(8 / 17)$ of patients aged $6-11$ years, $28.6 \%$ $(8 / 28)$ of those aged $12-17$ years, $30.4 \%(7 / 23)$ of those aged $18-25$ years, and $13.2 \%$ (5/38) of those aged 26 years or older patients). Mean \pm SD cCMA was $0.69 \pm 0.28$ for oral forms of anti-infectives and did not differ between age groups ( $p=0.7723$; Table 3$)$; less than half $(56 / 122$, $45.9 \%$ ) of patients had a $\mathrm{CMA}>0.8$.

\section{Discussion}

The present study found that among adult and pediatric French CF patients, the mean cCMA was 0.67 and for all age groups was above 0.50 . These results are consistent with data from the latest targeted literature review, although the study population and the therapeutic classes studied in this study are more extensive. ${ }^{7}$ Despite French NHI allows a free providing of all drugs that have been covered in the study, adherence rates do not seem to be notably higher than in countries without this system. The financial barrier does not seem to be the main barrier to adherence. 
Adherence varied according to age group, the highest cCMA was found in children it then decreased in adolescents aged and further so in young adults, and finally increased slightly in older adults. This could be attributed to the gradual increase in the autonomy of patients who are supervised in childhood by their parents and then gradually managing their treatment alone. According to Faint et al, disease knowledge of adolescents remained suboptimal shortly before transition to adult care (age 15-17 years) and some adolescents appear to be inadequately prepared to assume the responsibility of managing their $\mathrm{CF}$ and making informed decisions about their medical treatment as adults. ${ }^{24}$ Moreover, Dziuban et al reported that $42 \%$ of teenagers did not feel the need to use their medications in the absence of symptoms, especially for the use of aerosol and nebulization device. ${ }^{25}$ This underlines that transition is a pivotal moment to reinforced therapeutic education to enhance young adults adherence.

Adherence also varied between pharmaceutical forms: patients were less adherent to inhaled therapies than oral medications, which is in agreement with previous findings. ${ }^{11,26}$ One aspect that could explain this is the more complex management and time-consuming use of inhaled medications, such as inhalation technique, nebulization time, or cleaning devices. ${ }^{24,27}$ Furthermore, previous studies have also suggested that $\mathrm{CF}$ patients are more likely to be adherent to treatments that offer immediate relief or give rise to immediate consequences in case of non-adherence (eg, abdominal pain or diarrhea for vitamins and digestive enzymes), rather than those that offer more long-term benefits, with considerable motivation and enforcement needed with such treatments. ${ }^{28}$ The present study also highlights that among inhaled medications the lowest adherence herein was found for inhaled drugs for obstructive airways disease (bronchodilators and corticosteroids), irrespective of age. This may be because health care professionals undervalue their clinical utility since their effectiveness in CF remains to be demonstrated. ${ }^{29}$

To the best of our knowledge, this is the first study to evaluate medication adherence for chronic treatments used by $\mathrm{CF}$ patients of all ages both overall and for therapeutic class. CF is a pathology whose scalability and diversity of care are difficult to compare with other diseases, and whose patient's adherence to one medication cannot reflect adherence to the entire treatment. The second main strength of the study is the use of CMA version 7 to evaluate medication adherence; this is based on both prescription and administrative claims data and allows an objective and reproducible measurement of medication adherence. ${ }^{21}$ The calculation accounted also for periods of hospitalization. It has been shown that administrative data allowed measurements closer to reality than self-reports that remains used in many studies. ${ }^{3,19,30-34}$ Others opted for electronic adaptive aerosol delivery device or electronic pill-caps, but owing to their cost, patient samples were small and adherence measurements involved only one drug or therapeutic class. ${ }^{35-39}$

The study does, however, have some limitations which can result in over estimation of adherence levels. The first is patient recruitment as less than half of those invited to participate did so. The study may therefore have been affected by selection bias as those who did not consent to participate are possibly those with worse adherence to treatment, and therefore the adherence levels reported in this article should be regarded as conservative estimates. The second limitation is due to the use of an administrative database that may overestimate the real administration of the drug may be lower than medication availability. However, in CF populations such a bias may not be a concern as Modi et al have reported that adherence rates from claims data were better than those estimated by selfreport measure substantially inflated by reporting biases and recall problems. ${ }^{19}$ Lastly, because of the method of calculation, CMA reflects medication adherence only for drugs with at least one dispensation during the follow-up period. In the present study, 67 patients had at least one medication prescribed that was not dispensed over the beginning of FUW until the end of OW. This may be due in some cases to patient non-adherence for a specific drug during the follow-up period and therefore CMA may be overestimated for overall medication adherence. However, some cases may also be related to the non-initiation of treatment, a dimension of medication adherence not included in this study evaluating both implementation and persistence.

\section{Conclusion}

This study suggests that adherence to medication regimens in CF patients remains suboptimal and may vary substantially between age groups and pharmaceutical forms. These variations in adherence should be considered when investigating determinants and when developing effective strategies to improve adherence. Following this study, a bundle of solutions for medication adherence for CF adult patients, co-constructed by a group of patients and health professionals, will be tested in a multicenter, open-label study in our regional CF centers. 


\section{Acknowledgments}

We thank Neziha Bensalem, Laetitia Bouveret, Sophie Hommey, Stephanie Polazzi, and Marie Perceval for their technical advice and their contribution during the implementation of the study and data collection. We also thank the Direction régionale du service médical Rhône-Alpes de la Caisse nationale d'Assurance maladie des travailleurs salariés (DRSM), the regional directorate of the French National Health Insurance for access to administrative claims data of its regional reimbursement database (Extraction, Recherches, Analyses pour un Suivi Medico-Economique, ERASME). This work was funded by the association Vaincre la Mucoviscidose (VLM) (RC20150501406).

\section{Author contributions}

MV, PC, ADenis, ADima, ID, and ST contributed to the study concept and design and SPB, HR, MV and ST participated in the conduct of the study. All authors contributed to the acquisition of data for the work. HR, MV, ADenis, and SA contributed to the data analysis, and HR, MV, ST, SA, QR, ADenis, ADima, and ID contributed toward drafting. All authors contributed toward critically revising the paper, gave final approval of the version to be published, and agree to be accountable for all aspects of the work.

\section{Disclosure}

Alexandra Lelia Dima report grants and non-financial support from Respiratory Effectiveness Group, outside the submitted work. The authors report no other conflicts of interest in this work.

\section{References}

1. Elborn JS. Cystic fibrosis. Lancet. 2016;388(10059):2519-2531. doi:10.1016/S0140-6736(16)00576-6

2. Registre français de la mucoviscidose. Bilan des données 2016 [French CF Registry. Data Report 2016]. Vaincre la Mucoviscidose et Institut national d'études démographiques (Ined) Paris, décembre 2017. Vaincre la Mucoviscidose. 2015. Available from: https://www.vaincrelamuco.org/ face-la-mucoviscidose/registre-et-muco-en-chiffres. Accessed February 1, 2018. French.

3. Sawicki GS, Sellers DE, Robinson WM. High treatment burden in adults with cystic fibrosis: challenges to disease self-management. $J$ Cyst Fibros. 2009;8(2):91-96. doi:10.1016/j.jcf.2008.09.007

4. Chin M, Aaron SD, Bell SC. The treatment of the pulmonary and extrapulmonary manifestations of cystic fibrosis. Presse Médicale. 2017;46(6):e139-64. doi:10.1016/j.lpm.2016.11.030

5. Ronan NJ, Elborn JS, Plant BJ. Current and emerging comorbidities in cystic fibrosis. Presse Médicale. 2017;46(6):e125-38.

6. O'Donohoe R, Fullen BM. Adherence of subjects with cystic fibrosis to their home program: a systematic review. Respir Care. 2014;59 (11):1731-1746.
7. Narayanan S, Mainz JG, Gala S, Tabori H, Grossoehme D. Adherence to therapies in cystic fibrosis: a targeted literature review. Expert Rev Respir Med. 2017;11(2):129-145.

8. Briesacher BA, Quittner AL, Saiman L, Sacco P, Fouayzi H, Quittell LM. Adherence with tobramycin inhaled solution and health care utilization. BMC Pulm Med. 2011;11:5.

9. Nasr SZ, Chou W, Villa KF, Chang E, Broder MS. Adherence to dornase alfa treatment among commercially insured patients with cystic fibrosis. J Med Econ. 2013;16(6):801-808.

10. Quittner AL, Zhang J, Marynchenko M, et al. Pulmonary medication adherence and health-care use in cystic fibrosis. Chest. 2014;146 (1):142-151. doi:10.1378/chest.13-1926

11. Eakin MN, Bilderback A, Boyle MP, Mogayzel PJ, Riekert KA. Longitudinal association between medication adherence and lung health in people with cystic fibrosis. J Cyst Fibros. 2011;10(4):258264. doi:10.1016/j.jcf.2011.03.005

12. Eakin MN, Riekert KA. The impact of medication adherence on lung health outcomes in cystic fibrosis. Curr Opin Pulm Med. 2013;19 (6):687-691. doi:10.1097/MCP.0b013e3283659f45

13. Balfour L, Armstrong M, Holly C, et al. Development and psychometric validation of a cystic fibrosis knowledge scale. Respirology. 2014;19(8):1209-1214. doi:10.1111/resp.12379

14. Feiten TDS, Flores JS, Farias BL, et al. Respiratory therapy: a problem among children and adolescents with cystic fibrosis. J Bras Pneumol. 2016;42(1):29-34. doi:10.1590/S1806-37562016000000068

15. Fender P, Weill A. [Epidemiology, public health and medical rates databases]. Rev Epidemiol Sante Publique. 2004;52(2):113-117. doi:10.1016/S0398-7620(04)99032-3

16. Adherence to Long-term Therapies: Evidence for Action. World Health Organisation. Available from: http://www.who.int/chp/knowledge/pub lications/adherence_report/en/. Accessed August 22, 2018.

17. Monégat M, Sermet C, Perronnin M, Rococo E. La polymédication : définitions, mesures et enjeux. Revue de la littérature et tests de mesure [Polypharmacy: definitions, measurement and stakes involved Review of the literature and measurement tests]. Questions d'économie de la santé : 2014 (état de santé, protection sociale, enquête, analyses économiques, comparaisons internationales) IRDES. irdes. Available from: http://www.irdes.fr/recherche/2014/ questions-d-economie-de-la-sante.html\#n204. Accessed September 10, 2018. French.

18. Vollmer WM, Xu M, Feldstein A, Smith D, Waterbury A, Rand C. Comparison of pharmacy-based measures of medication adherence. BMC Health Serv Res. 2012;12:155. doi:10.1186/1472-6963-12-155

19. Modi AC, Lim CS, Yu N, Geller D, Wagner MH, Quittner AL. A multi-method assessment of treatment adherence for children with cystic fibrosis. J Cyst Fibros. 2006;5(3):177-185. doi:10.1016/j. jcf.2006.03.002

20. Vrijens B, De Geest S, Hughes DA, et al. A new taxonomy for describing and defining adherence to medications: new taxonomy for adherence to medications. Br J Clin Pharmacol. 2012;73 (5):691-705. doi:10.1111/j.1365-2125.2012.04167.x

21. Dima AL, Dediu D. Computation of adherence to medication and visualization of medication histories in $\mathrm{R}$ with AdhereR: towards transparent and reproducible use of electronic healthcare data. PLoS One. 2017;12(4):e0174426. doi:10.1371/journal.pone.0174426

22. Pednekar $\mathrm{P}$, Malmenas $\mathrm{M}$, Ágh $\mathrm{T}$, Bennett $\mathrm{B}$, Peterson A. Measuring Multiple Medication Adherence-Which Measure When? ISPOR | International Society For Pharmacoeconomics and Outcomes Research. Available from: https://www.ispor.org/publica tions/journals/value-outcomes-spotlight/abstract/november-decem ber-2017/measuring-multiple-medication-adherence-which-measurewhen. Accessed August 27, 2018.

23. $\mathrm{R}$ Core Team. R: A Language and Environment for Statistical Computing [internet]. Vienna, Austria: R Foundation for Statistical Computing; 2013. Available from: https://www.r-project.org/. Accessed March 8, 2019. 
24. Faint NR, Staton JM, Stick SM, Foster JM, Schultz A. Investigating self-efficacy, disease knowledge and adherence to treatment in adolescents with cystic fibrosis: adherence in cystic fibrosis treatment. $J$ Paediatr Child Health. 2017;53(5):488-493. doi:10.1111/jpc.2017. 53.issue-5

25. Dziuban EJ, Saab-Abazeed L, Chaudhry SR, Streetman DS, Nasr SZ. Identifying barriers to treatment adherence and related attitudinal patterns in adolescents with cystic fibrosis. Pediatr Pulmonol. 2010;45(5):450-458. doi:10.1002/(ISSN)1099-0496

26. White H, Shaw N, Denman S, Pollard K, Wynne S, Peckham DG. Variation in lung function as a marker of adherence to oral and inhaled medication in cystic fibrosis. Eur Respir J. 2017;49:3. doi:10.1183/13993003.00987-2016

27. Keyte R, Egan H, Jackson C, Nash E, Regan A, Mantzios M. A weekend/weekday comparison of adherence to daily treatment regimens in adults with cystic fibrosis. Health Psychol Rep. 2018;6 (2): 146-157.

28. Dodd ME, Webb AK. Understanding non-compliance with treatment in adults with cystic fibrosis. $J R$ Soc Med. 2000;93(Suppl 38):2-8.

29. Smith S, Edwards CT. Long-acting inhaled bronchodilators for cystic fibrosis. Cochrane Database Syst Rev. 2017;19(12):CD012102.

30. Harrison MJ, McCarthy M, Fleming C, et al. Inhaled versus nebulised tobramycin: a real world comparison in adult cystic fibrosis (CF). J Cyst Fibros. 2014;13(6):692-698. doi:10.1016/j.jcf.2014.04.004

31. Lin -AH-A, Kendrick J, Wilcox PG, Quon BS. Patient knowledge and pulmonary medication adherence in adult patients with cystic fibrosis. Patient Prefer Adherence. 2017;11:691-698. doi:10.2147/ PPA.S134792

32. Blasi F, Carnovale V, Cimino G, et al. Treatment compliance in cystic fibrosis patients with chronic Pseudomonas aeruginosa infection treated with tobramycin inhalation powder: the FREE study. Respir Med. 2018;138:88-94. doi:10.1016/j.rmed.2018.03.034
33. Dempster NR, Wildman BG, Masterson TL, Omlor GJ. Understanding treatment adherence with the health belief model in children with cystic fibrosis. Health Educ Behav. 2018;45(3):435443. doi: $10.1177 / 1090198117736346$

34. Daniels T, Goodacre L, Sutton C, Pollard K, Conway S, Peckham D. Accurate assessment of adherence: self-report and clinician report vs electronic monitoring of nebulizers. Chest. 2011;140(2):425-432. doi:10.1378/chest.11-0401

35. Bakker EM, Volpi S, Salonini E, et al. Improved treatment response to dornase alfa in cystic fibrosis patients using controlled inhalation. Eur Respir J. 2011;38(6):1328-1335. doi:10.1183/09031936.00006211

36. McCormack P, Southern KW, McNamara PS. New nebulizer technology to monitor adherence and nebulizer performance in cystic fibrosis. J Aerosol Med Pulm Drug Deliv. 2012;25(6):307-309. doi:10.1089/jamp.2011.0934

37. Ball R, Southern KW, McCormack P, Duff AJA, Brownlee KG, McNamara PS. Adherence to nebulised therapies in adolescents with cystic fibrosis is best on week-days during school term-time. $J$ Cyst Fibros. 2013;12(5):440-444. doi:10.1016/j.jcf.2012.11.014

38. Siracusa CM, Ryan J, Burns L, et al. Electronic monitoring reveals highly variable adherence patterns in patients prescribed ivacaftor. $J$ Cyst Fibros. 2015;14(5):621-626. doi:10.1016/j.jcf.2015.05.005

39. Barker DH, Quittner AL. Parental depression and pancreatic enzymes adherence in children with cystic fibrosis. Pediatrics. 2016;137(2): e20152296. doi:10.1542/peds.2015-2296 


\section{Supplementary material}

Table SI CF therapeutic medications used in long term by patients of the study

\begin{tabular}{|c|c|c|c|c|}
\hline $\mathbf{N}^{\circ}$ & ATC code & ATC denomination & Form & International non-proprietary names (INN) \\
\hline \multirow[t]{5}{*}{ I } & \multirow[t]{5}{*}{$\mathrm{A} 02$} & \multirow[t]{5}{*}{ Drugs for acid-related disorders } & \multirow[t]{5}{*}{ Oral } & Esomeprazole \\
\hline & & & & Lansoprazole \\
\hline & & & & Omeprazole \\
\hline & & & & Pantoprazole \\
\hline & & & & Sucralfate \\
\hline 2 & $\mathrm{~A} 05$ & Bile acids & Oral & Ursodeoxycholic acid \\
\hline 3 & A09 & Digestives enzymes & Oral & Multienzymes (lipase, protease, etc.) \\
\hline \multirow[t]{9}{*}{4} & \multirow[t]{9}{*}{ AlO } & \multirow[t]{9}{*}{ Antidiabetics } & \multirow[t]{8}{*}{ Injected } & Insulin asparte \\
\hline & & & & Insulin asparte-protamine \\
\hline & & & & Insulin detemir \\
\hline & & & & Insulin glargine \\
\hline & & & & Insulin glulisine \\
\hline & & & & Insulin lispro \\
\hline & & & & Insulin lispro-protamine I:I \\
\hline & & & & Insulin lispro-protamine I:4 \\
\hline & & & Oral & Repaglinide \\
\hline \multirow[t]{7}{*}{5} & \multirow{7}{*}{$\begin{array}{l}\mathrm{A} 1 \mathrm{I} \\
\mathrm{A} 12 \\
\mathrm{~B} 02\end{array}$} & \multirow[t]{7}{*}{ Vitamins and mineral supplements } & \multirow[t]{7}{*}{ Oral } & Calcium carbonate \\
\hline & & & & Calcium, combinations with vitamin D \\
\hline & & & & Colecalciferol \\
\hline & & & & Ergocalciferol \\
\hline & & & & Phytomenadione \\
\hline & & & & Retinol (vit A) \\
\hline & & & & Tocopherol (vit E) \\
\hline \multirow[t]{9}{*}{6} & \multirow{9}{*}{$\begin{array}{l}\text { J0I } \\
\text { J02 } \\
\text { J04 } \\
\text { J05 }\end{array}$} & \multirow[t]{9}{*}{ Oral anti-infectives } & \multirow[t]{9}{*}{ Oral } & Amoxicilline and beta-lactamase inhibitor \\
\hline & & & & Azithromycin \\
\hline & & & & Cefadroxil \\
\hline & & & & Cefpodoxime \\
\hline & & & & Ciprofloxacin \\
\hline & & & & Clarithromycin \\
\hline & & & & Clofazimine \\
\hline & & & & Doxycycline \\
\hline & & & & Erythromycin \\
\hline
\end{tabular}

(Continued) 
Table SI (Continued).

\begin{tabular}{|c|c|c|c|c|}
\hline $\mathbf{N}^{\circ}$ & ATC code & ATC denomination & Form & International non-proprietary names (INN) \\
\hline & & & & Ethambutol \\
\hline & & & & Itraconazole \\
\hline & & & & Minocycline \\
\hline & & & & Moxifloxacin \\
\hline & & & & Posaconazole \\
\hline & & & & Pristinamycin \\
\hline & & & & Sulfamethoxazole and trimethoprim \\
\hline \multirow[t]{6}{*}{7} & & \multirow[t]{6}{*}{ Inhaled anti-infectives } & \multirow[t]{2}{*}{ Nebulization } & Amphotericin B \\
\hline & & & & Aztreonam \\
\hline & & & Aerosol & \multirow[t]{2}{*}{ Colistin } \\
\hline & & & Nebulization & \\
\hline & & & Aerosol & \multirow[t]{2}{*}{ Tobramycin } \\
\hline & & & Nebulization & \\
\hline \multirow[t]{17}{*}{8} & \multirow[t]{17}{*}{ R03 } & \multirow[t]{17}{*}{ Drugs for obstructive airways disease } & Aerosol & Beclometasone \\
\hline & & & Aerosol & \multirow[t]{2}{*}{ Budesonide } \\
\hline & & & Nebulization & \\
\hline & & & \multirow[t]{6}{*}{ Aerosol } & Fenoterol and ipratropium bromide \\
\hline & & & & Fluticasone \\
\hline & & & & Formoterol \\
\hline & & & & Formoterol and beclometasone \\
\hline & & & & Formoterol and budesonide \\
\hline & & & & Indacaterol \\
\hline & & & Nebulization & Ipratropium bromide \\
\hline & & & Oral & Montelukast \\
\hline & & & Injected & Omalizumab \\
\hline & & & Nebulization & Salbutamol \\
\hline & & & \multirow[t]{2}{*}{ Aerosol } & Salmeterol \\
\hline & & & & Salmeterol and fluticasone \\
\hline & & & Oral & \multirow[t]{2}{*}{ Terbutaline } \\
\hline & & & Nebulization & \\
\hline 9 & R05 & Mucolytics & Nebulization & Dornase alfa (desoxyribonuclease) \\
\hline 10 & R07 & CFTR potentiator & Oral & Ivacaftor \\
\hline
\end{tabular}

Abbreviations: $\mathrm{CF}$, cystic fibrosis ; CFTR, cystic fibrosis transmembrane conductance regulator. 


\section{Publish your work in this journal}

Patient Preference and Adherence is an international, peer-reviewed, open access journal that focusing on the growing importance of patient preference and adherence throughout the therapeutic continuum. Patient satisfaction, acceptability, quality of life, compliance, persistence and their role in developing new therapeutic modalities and compounds to optimize clinical outcomes for existing disease

states are major areas of interest for the journal. This journal has been accepted for indexing on PubMed Central. The manuscript management system is completely online and includes a very quick and fair peer-review system, which is all easy to use. Visit http:// www.dovepress.com/testimonials.php to read real quotes from published authors. 